\title{
11. BIOSTRATIGRAPHIC AND PALEOENVIRONMENTAL STUDY OF PALEOCENE BENTHIC AND PLANKTONIC FORAMINIFERS, SITE 605, DEEP SEA DRILLING PROJECT LEG $93^{1}$
}

\author{
Pierre Saint-Marc, Laboratoire de Micropaléontologie et de Géologie Marines, Université de Nice²
}

\begin{abstract}
Paleocene benthic and planktonic foraminifers occur throughout a long interval of the sedimentary succession cored at Site 605. A biostratigraphic zonation based on planktonic foraminifers is proposed for this Paleocene section. Zones identified are Subbotina pseudobulloides Zone, Morozovella trinidadensis Zone, M. uncinata Zone, M. pusilla pusilla Zone, Planorotalites pseudomenardii Zone, and $M$. velascoensis Zone. Fluctuations in the sedimentation rate occurred at Site 605. Rates of deposition were high during the $M$. pusilla pusilla and $P$. pseudomenardii zones, and a depositional hiatus may occur at the base of the $M$. velascoensis Zone. Qualitative and quantitative analysis of benthic foraminiferal assemblages suggests that the Paleocene sediments of Site 605 were deposited near the upper limit of Nuttallides truem$p y i$, that is, approximately in the middle bathyal zone ( $600 \mathrm{~m}$ or more).
\end{abstract}

\section{INTRODUCTION}

Site 605 is located on the uppermost continental rise of the New Jersey Transect, in $2197 \mathrm{~m}$ of water, 100 miles southeast of Atlantic City, New Jersey (Fig. 1). Hole 605 was cored to $816.7 \mathrm{~m}$ and penetrated five lithologic units (Fig. 2). The oldest sediments drilled at this site (Subunit VB) are Maestrichtian in age. The Cretaceous/Tertiary boundary was reached at $760.2 \mathrm{~m}$. The Paleocene section (Subunit VA and Unit IV) lies between $564 \mathrm{~m}$ (Paleocene/Eocene boundary) and $760.2 \mathrm{~m}$. The lowermost Paleocene sediments (Subunit VA), $77 \mathrm{~m}$ thick, are composed of olive gray clayey limestones, rich in terrigenous silt (15-20\%) and glauconite (2-4\%). Unit IV, of middle and late Paleocene age, is made up of $176 \mathrm{~m}$ of dark greenish gray clayey nannofossil limestones. This unit is characterized by well-developed marl-limestone cycles and frequent bioturbation (Zoophycos burrows).

This chapter discusses the planktonic and benthic foraminifers identified from the Paleocene sedimentary section recovered at Site 605 . The primary objective of this study was to correlate Paleocene strata using standard planktonic foraminiferal zonations. A further objective was to investigate the benthic foraminiferal assemblages in the Paleocene sediments in order to interpret the environmental conditions of their deposition.

\section{PREPARATION OF SAMPLES}

Samples were prepared by standard methods. First, $10-\mathrm{cm}^{3}$ samples were dried in a oven at $80-100^{\circ} \mathrm{C}$ for about $12 \mathrm{hr}$. for a dried sample weight of $\sim 10-20 \mathrm{~g}$. The weakly cemented sediment was disaggregated in water to which was added a spoonful of Calgon. This mixture was boiled for a few minutes to aid in disaggregation and partially clean the foraminifers. The treated samples were wet-sieved with a $0.160-\mathrm{mm}$ mesh screen. The dried residue was examined for foraminifers.

Some planktonic foraminifers were picked for taxonomic and biostratigraphic determination. All of the benthic foraminifers $(>0.160$

\footnotetext{
${ }^{1}$ van Hinte, J. E., Wise, S. W., Jr., Init. Repts. DSDP, 93: Washington (U.S. Govt. Printing Office).

2 Address: Laboratoire de Micropaléontologie et de Géologie Marines, Université de Nice . Parc Valrose, 06034 Nice Cedex, France.
}

$\mathrm{mm}$ ) were picked for a qualitative taxonomic determination and a subsequent quantitative study designed to provide tools for understanding paleoecologic and paleoceanographic conditions.

Ratios calculated from the foraminiferal abundance data include (1) planktonic foraminifers/total microfauna, (2) agglutinated benthic foraminifers/all benthic foraminifers, and (3) abundance of benthic foraminifers expressed as specimens/g dry sediment.

\section{BIOSTRATIGRAPHY}

General agreement exists about the main Paleocene stratigraphic subdivisions based on the evolution of planktonic foraminifers. Among the numerous zonations proposed for the Paleocene interval, we have combined the zonations of Bolli (1966) and Hardenbol and Berggren (1978). Figure 3 gives ranges for common Paleocene planktonic foraminiferal species from Site 605 . The planktonic foraminiferal species concepts used here are those of Stainforth et al. (1975). The generic concepts adopted are those of Boersma and Premoli Silva (1983).

Above the Abathomphalus mayaroensis Zone, which is latest Maestrichtian in age, the following zones have been identified in the Paleocene section:

1. An undetermined zone at the top of Core 66 (60566-1, 0-120 cm; no sample available) (see Smit and Van Kempen, this volume).

2. The Subbotina pseudobulloides Zone (P1b) (Core 605-65) with its index species Globoconusa daubjergensis, S. triloculinoides, S. cf. fringa (in the lower part only), and Planorotalites cf. compressa (in the upper part).

3. The Morozovella trinidadensis Zone (P1c) (Sample $605-64, C C)$, with the index species, $M$. cf. inconstans, $P$. cf. compressa, S. pseudobulloides, and S. triloculinoides.

Sample $605-64-4,90-92 \mathrm{~cm}$ is entirely barren of planktonic foraminifers but contains some deep-sea benthic foraminifers (Nuttallides, Bulimina, Stilostomella), the tests of which are partly destroyed by dissolution.

4. The $M$. uncinata Zone (P2) was identified in the upper part of lithologic Subunit VA (Sample 605-64-2, $90-92 \mathrm{~cm}$ ), based on the presence of $M$. uncinata, $M$. trinidadensis, M. cf. inconstans, Subbotina pseudobulloides, and $S$. triloculinoides. 


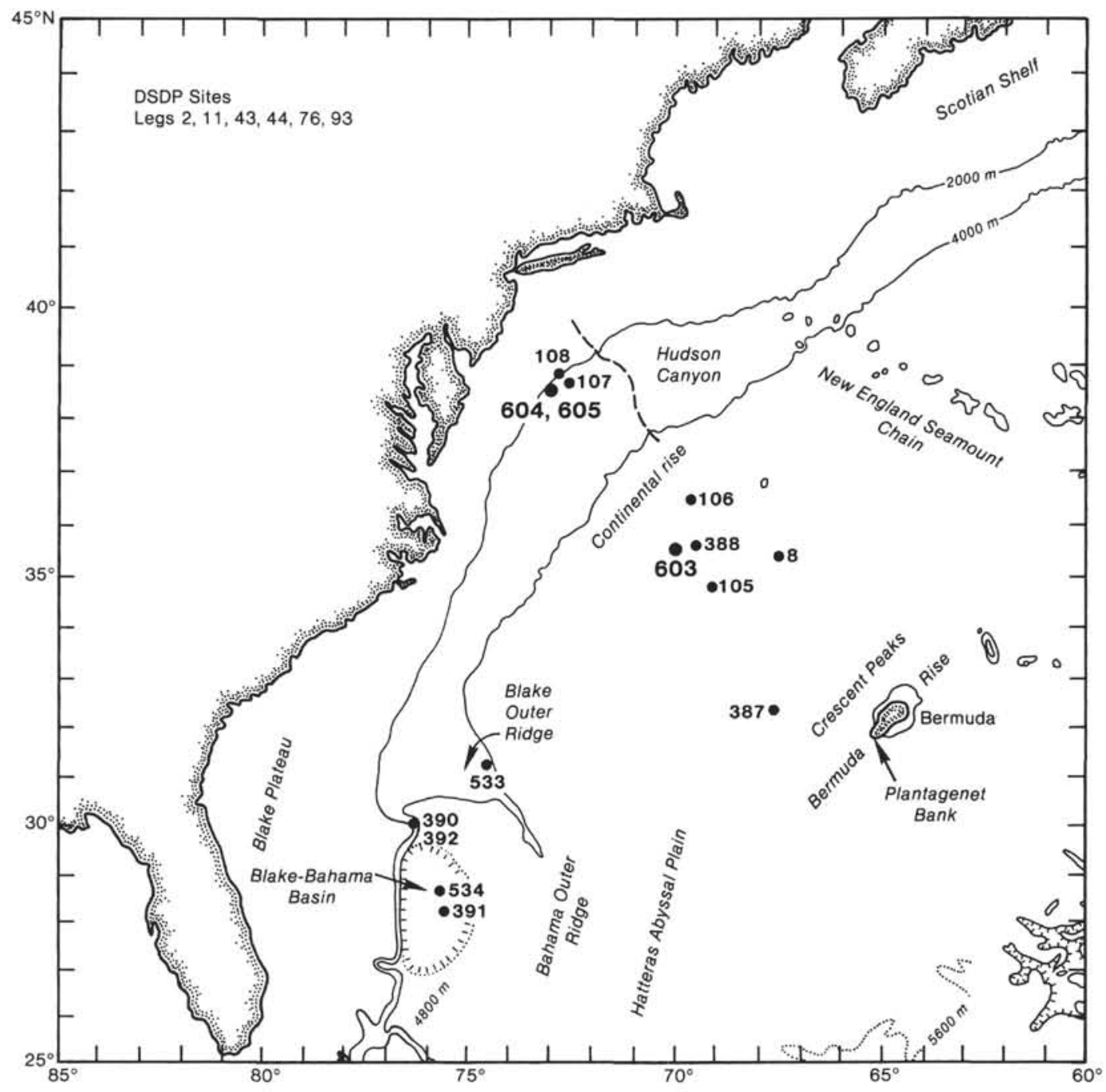

Figure 1. Location map with physiographic features of the North American Basin and location of Site 605 .

The interval from Sample 605-64-1, $54 \mathrm{~cm}$ to the upper part of Core 605-63 is characterized by low-carbonate sediments in which only radiolarians were identified. This span may represent the $M$. angulata Zone (P3a).

5. The Morozovella pusilla pusilla Zone (P3b) was identified in samples from Core 605-57 to Core 605-62. Many specimens of the index species are associated with $M$. cf. angulata, M. conicotruncana, $P$. chapmani, $P$. cf. compressa, Acarinina velascoensis, and S. triloculinoides.

6. The $P$. pseudomenardii Zone $(\mathrm{P} 4)$ was identified from Sample 605-46-4, 90-92 $\mathrm{cm}$ to Core 605-56 by the presence of the zonal species, associated with $P$. chapmani, $M$. acuta, and A. velascoensis. The $P$. pseudomenardii Zone can be subdivided into two parts: a lower part with $S$. triloculinoides, $M$. conicotruncana, and an upper part with $M$. velascoensis, $M$. cf. occlusa, $M$. cf. aequa, and $A$. nitida.

7. The $M$. velascoensis Zone s.1. was present from Sample 605-44-5, $33 \mathrm{~cm}$ to Sample 605-46-2, 90-92 cm and can be subdivided into two subzones, the lower characterized by the predominance of the index species, and the upper by the appearance of M. subbotinae. At Site
605 these two subzones are unequally present. The thinness of the lower subzone suggests a depositional hiatus between the $P$. pseudomenardii and the $M$. velascoensis zones.

8. The $M$. subbotinae Zone, earliest Eocene in age, has been identified from Sample 605-42,CC to Sample $605-44-5,33 \mathrm{~cm}$. Along with the index species there appear Pseudohastigerina wilcoxensis, M. formosa gracilis, $M$. marginodentata, and $A$. broedermanni.

\section{SEDIMENT ACCUMULATION RATES}

Sediment accumulation rates for the Paleocene section recovered in Cores 44 to $65(196.2 \mathrm{~m})$ of Site 605 were calculated using planktonic foraminiferal stratigraphy. The geochronometric scale and the biostratigraphic units used here are those given by Hardenbol and Berggren (1978).

The sediment accumulation rate was relatively low (6 $\mathrm{m} / \mathrm{Ma}$ ) during the early Paleocene (Subbotina pseudobulloides Zone to Morozovella angulata Zone). This low rate was accompanied by a high percentage of planktonic foraminifers $(>50 \%)$. This period was followed by one of high sedimentation rates $(50 \mathrm{~m} / \mathrm{Ma})$, and low per- 


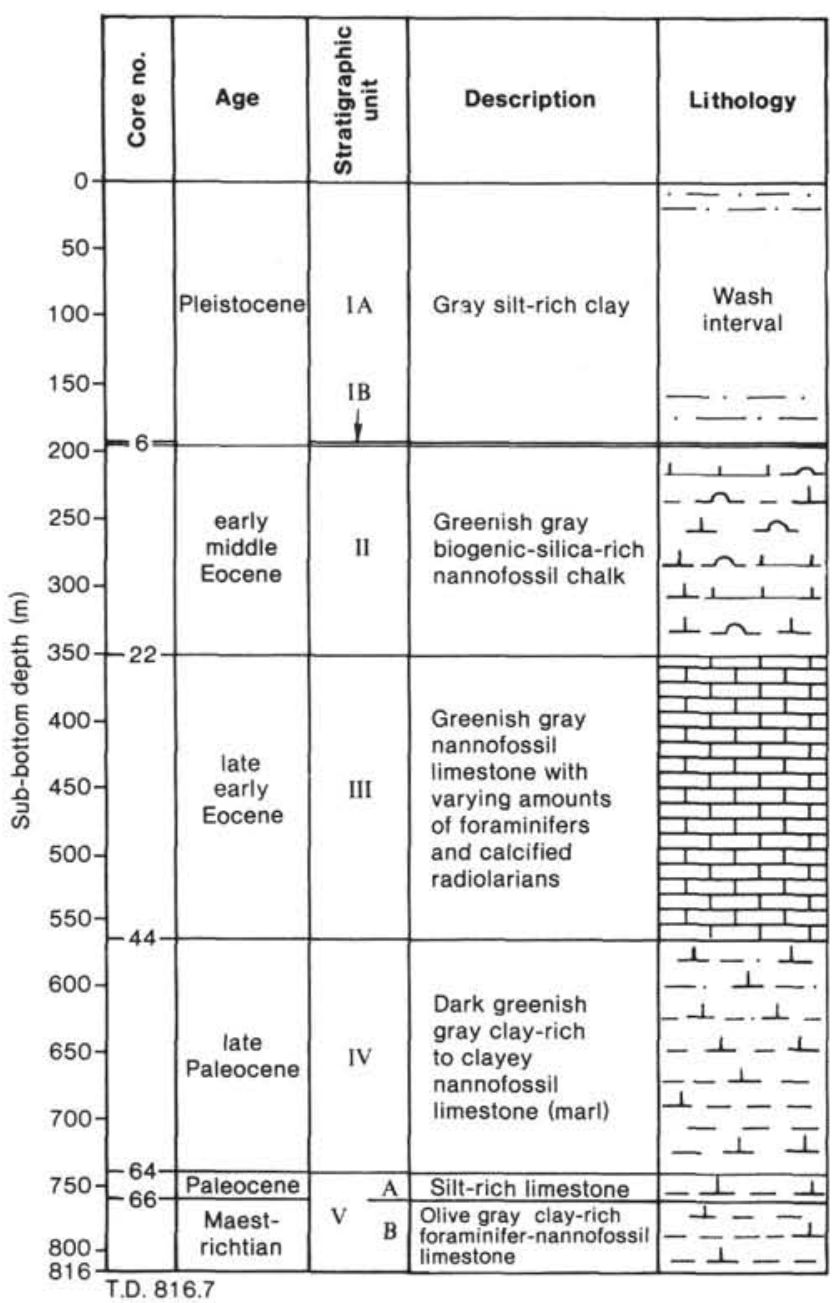

Figure 2. Stratigraphic summary of Site 605 .

centage of planktonic foraminifers $(\leq 50 \%)$, (M. pusilla pusilla $(\mathrm{P} 3 \mathrm{~b})$ and Planorotalites pseudomenardii $(\mathrm{P} 4)$ zones). A hiatus appears to be present between the $P$. pseudomenardii Zone ( $\mathrm{P} 4)$ and the $M$. velascoensis Zone (P5), and the sedimentation rate during the late Paleocene is consequently impossible to estimate. In the uppermost part of the Paleocene section, however, the percentage of planktonic foraminifers is very high ( $95-99 \%)$, suggesting either a lower rate of sedimentation or higher productivity of foraminifers during this period.

\section{PALEOENVIRONMENTAL CONDITIONS}

The distribution of deep-water benthic foraminifers is in part related to depth, but recent studies (Douglas and Woodruff, 1981) have shown that other factors, such as temperature, marine current, carbonate saturation, and substrate, are also of primary importance. Paleocene benthic foraminifers are so unlike modern and Neogene species and genera that paleodepth estimates can no longer be based upon faunal comparisons. Some estimates of paleodepth can be obtained, however, from the presence of certain genera (Pullenia, Stilostomella) that in the modern habitat are exclusively represented by deep-water species.
Considerable progress has been made in our understanding of Paleocene deep-water benthic foraminifers. According to Berggren and Aubert (1975), three major types of Paleocene benthic foraminiferal assemblages indicate deposition at depths ranging from inner neritic to abyssal. The assemblage characterized by Gavelinella rubiginosa, G. velascoensis, G. beccariiformis, Nuttallides truempyi, Nuttallinella florealis, Aragonia velascoensis, Osangularia velascoensis, and Gaudryina pyramidata, called the "Velasco-type" faunal assemblage (Cushman, 1926; Cushman and Renz, 1946; White, 1928-1929), has, from general geologic considerations, been determined to represent a deep-water environment. All these very distinctive species were identified at Site 605 , and it is thus easy to determine that Paleocene benthic foraminifers at this site originated in deep water $(>200 \mathrm{~m})$, but it is difficult to state how deep the water was.

We can place some constraints upon the depth of deposition of Paleocene sediments at Site 605 by the episodic occurrence of Nuttallides truempyi. This very distinctive benthic foraminifer, Maestrichtian to latest Eocene in age, is one of the dominant lower bathyal-abyssal taxa. Berggren and Aubert (1983) suggest an upper depth limit of 500-600 m between upper and middle bathyal depths, for this taxon, which does not occur in neritic assemblages ("Midway-type" assemblage). Thus, $N$. truempyi may be a good paleobathymetric marker, and if we take its presence or absence as a reference index, we can distinguish in the Paleocene sequence of Site 605 a succession of four foraminiferal assemblages (Table 1):

1. From $605-65, \mathrm{CC}$ to $605-61-5,90-92 \mathrm{~cm}$, very abundant $N$. truempyi is associated with numerous specimens of Bulimina trinitatensis.

2. From $605-59, \mathrm{CC}$ to $605-53, \mathrm{CC} N$. truempyi is absent. In this interval, Pullenia coryelli is dominant and some Midway-type foraminifers are identified: Tritaxia midwayensis, Eponides cf. plummerae, Cibicidoides alleni, and Gavelinella danica.

3. From $605-52, \mathrm{CC}$ to $605-48, \mathrm{CC}, N$. truempyi is common and is associated with numerous specimens of Spiroplectammina spectabilis.

4. From $605-47, C C$ to $605-44-6,90-92 \mathrm{~cm}, N$. truempyi is absent. Other Velasco-type foraminifers are frequent and are associated with apparently autochthonous Midway-type foraminifers such as Bulimina midwayensis, Cibicidoides alleni, C. aff. succedens, and Gavelinella danica.

In these four foraminiferal assemblages, some species almost always present are Spiroplectammina spectabilis, Gaudryina pyramidata, Eggerella trochoidea, Nodosaria velascoensis, Pullenia gr. quinqueloba, Osangularia velascoensis, Anomalinoides praespissiformis, Gavelinella beccariiformis, and $G$. velascoensis.

The sporadic occurrence of Nuttallides truempyi and the dominance of Velasco-type foraminifers intercalated with Midway-type microfauna suggest deposition of the Paleocene sequence in middle bathyal depths, near the upper limit of the depth range of $N$. truempyi.

At first glance, the succession of the four Paleocene foraminiferal assemblages could be explained, from bot- 


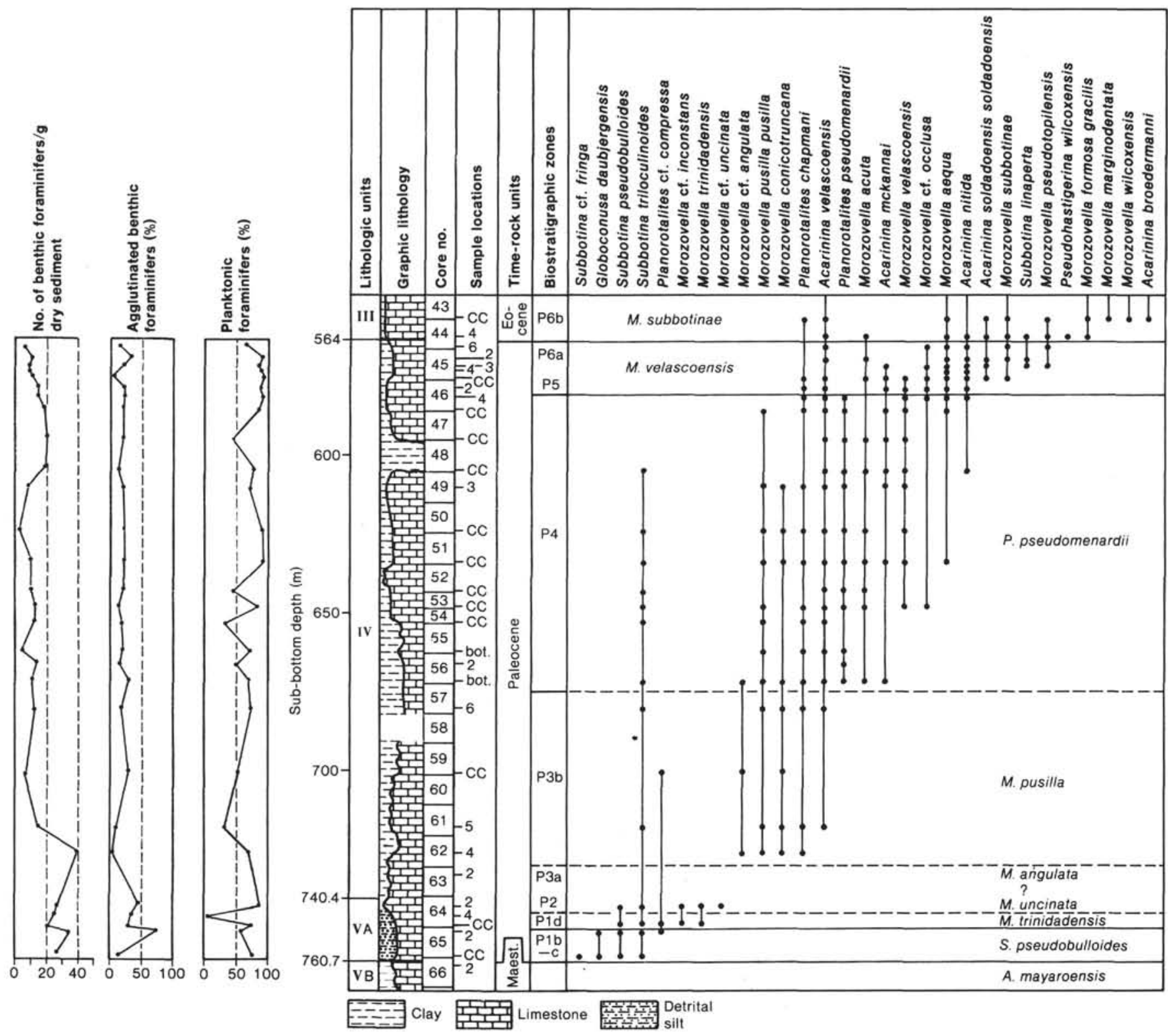

Figure 3. Range of selected planktonic foraminifers, biostratigraphic subdivisions, and quantitative data for planktonic and benthic foraminifers from the Paleocene of Hole 605.

tom to top, by lowering of the sea level. In the basal Paleocene, Nuttallides truempyi predominates; it progressively disappears upward. In upper layers, Midway-type foraminifers, apparently autochthonous and normally developed in shelf facies $(<200 \mathrm{~m}$; Berggren and $\mathrm{Au}-$ bert, 1975; Aubert and Berggren, 1976), are associated with Velasco-type foraminifers. But this supposed lowering of sea level is contradicted by the geologic context (deepening of the Atlantic Ocean) and by the hypothesis of global changes of sea level proposed by Vail et al. (1977), in which the late Paleocene is characterized by a progressive rise in the sea level.

Foraminiferal distribution patterns are related to water mass distribution (Berggren, 1978) rather than absolute depth, and there seems no justification for interpreting minor bathyal faunal changes as a result of epei- rogenetic uplift or sea level change. Rather they may indicate changes in bottom-water properties caused by climatic events or bottom currents. Berggren and Schnitker (1983) postulated, from a variety of sources, that during the Paleocene and Eocene the marine climate of the North Atlantic ranged from subtropical at low latitudes to warm temperatures at high latitudes, and that the continental climates on adjacent land areas were predominantly warm and humid. Haq et al. (1977) studied the spatial and temporal distributions of early Cenozoic calcareous plankton of the Atlantic Ocean and interpreted the temporal oscillations of the assemblages as the results of climatic fluctuations. They postulated cool climates during the earliest Paleocene (65-63 Ma), relatively warm climates from 63 to $60 \mathrm{Ma}$ ("middle" Paleocene), a cooling episode between 60 and $57 \mathrm{Ma}$ (late Pa- 
leocene), with a peak near $59 \mathrm{Ma}$, and a warm interval in the latest Paleocene and early Eocene, with one minor cooling around 54-53 Ma (Paleocene/Eocene boundary).

The three first climatic periods of the Paleocene postulated by Haq et al. (1977) are not obvious in the studied section. However, Ceratobulimina perplexa is present in two intervals: from 605-65,CC to 605-64-4, 90-92 $\mathrm{cm}$ and from 605-59, CC to 605-56-2, 90-92 cm, sediments deposited approximately during the inferred "cool" periods of the Paleocene (Zone P1, upper part of Zone P3, and basal part of Zone P4). This benthic foraminiferal assemblage has an apparently disjunct midlatitude distribution in the Northern and Southern Hemispheres (McGowran, 1966) and may be related to colder bottom water, but proof is lacking. The warm interval of the late Paleocene is marked at Site 605 by dominantly carbonate deposition (from 605-47, CC to 605-45-2, 90-92 cm), and by the occurrence of Midway-type fauna in Velascotype assemblages. It seems that these Midway-type species constitute autochthonous components of foraminiferal assemblages; their presence does not appear to be linked to downslope transport. The occurrence of these shallow benthic foraminifers in deep-sea sediments could be explained by expanded depth ranges of these species caused by hydrographic changes.

There are few DSDP sites with comparable paleobathymetric conditions. Paleocene sections at other sites were generally deposited in deeper water. The environment of deposition was probably abyssal for Site 400 , abyssal to lower bathyal for Sites 361 and 401, and lowermiddle bathyal for Sites 236, 363-364, and 208 (Schnitker, 1979; Proto Decima and Bolli, 1978; Vincent et al., 1974; Webb, 1972). However, Site 237 (Vincent et al., 1974), located in the Mascarene Plateau of the Indian Ocean, and Site 329, located on the Maurice Ewing Bank of the South Atlantic (Tjalsma, 1977), show strong faunal similarities with Site 605 (Table 2). Deposition was postulated as upper bathyal to upper abyssal (200-2500 $\mathrm{m})$ at Site 237 and mid to lower bathyal (600-1800 m) at Site 329 . This agrees with our hypothesis assigning a depositional depth in the mid to lower bathyal zone (600$1800 \mathrm{~m}$ ) to the Paleocene section of Site 605 .

\section{CONCLUSIONS}

The sedimentary history of the Paleocene in the North Atlantic is not very well known, for this period is poorly represented in deep-sea sequences. Its widespread absence is partly due to the formation of deep-sea unconformities. Thus Hole 605 , which penetrated a near-complete sedimentary sequence of Paleocene age, furnishes interesting data on the deposits, the sediment accumulation rates, and the paleoenvironment of this period in the northeastern Atlantic. Paleocene strata of Site 605 have been correlated with standard zonations of planktonic foraminifers. The following zones have been identified: the Subbotina pseudobulloides Zone, the Morozovella trinidadensis Zone, the $M$. uncinata Zone, the M. pusilla pusilla Zone, the Planorotalites pseudomenardii Zone, and the $M$. velascoensis Zone. The $M$. an- gulata Zone has not been identified. The sedimentation rate fluctuates, with a high rate of deposition during the $M$. pusilla pusilla and $P$. pseudomenardii zones. A depositional hiatus is presumed to be present at the base of the $M$. velascoensis Zone. Qualitative and quantitative analysis of the rich and well-preserved benthic foraminiferal assemblages has allowed us to assign the $\mathrm{Pa}$ leocene section of Site 605 a depositional depth in the middle bathyal zone ( $600 \mathrm{~m}$ or more).

\section{SPECIES REFERENCE LIST}

There is a considerable literature dealing with Paleocene benthic foraminiferal taxonomy, but compared with the volume of knowledge that is available about shallow-water benthic foraminifers, our existing knowledge of Paleocene deep-water foraminifers is scanty indeed. As usual in the literature on foraminifers, it is clear that the same species has been recorded under different names, although recent micropaleontologic works on Paleocene strata have considerably clarified foraminiferal taxonomy (Tjalsma and Lohmann, 1983). A thorough taxonomic discussion of the Paleocene benthic foraminifers of Site 605 is consequently beyond the scope of this article.

The majority of the species mentioned in this report are well known in the literature. A reference to the type-species of each identified benthic foraminifer is given here, with complementary reference(s) to complete descriptions, illustrations, and synonymies.

Ammodiscus cretaceus (Reuss). Operculina cretacea, Reuss, 1845, Die Versteinerungen der Böhmische Kreideformation (Stuttgart), 1:35, figs. 64-65. Ammodiscus cretaceus (Reuss), Gradstein and Berggren, 1981, Mar. Micropaleontol., 6(3):241, pl. 2, fig. 3.

Ammodiscus peruvianus Berry, 1928. Eclog. Geol. Helv., 21:342, pl. 27. Gradstein and Berggren, 1981, Mar. Micropaleontol., 6(3):241-242, pl. 2, figs. 14-15.

Glomospira gordialis (Jones and Parker). Trochammina squamata var. gordialis, Jones and Parker, 1860, Q. J. Geol. Soc. London. 16: 304. Glomospira gordialis (Jones and Parker), Gradstein and Berggren, 1981, Mar. Micropaleontol., 6(3):246, pl. 3, figs. 2-3.

Hormosina ovulum (Grzybowski). Reophax ovulum, Grzybowski, 1896, Rozpr. Ajad. Um. Wydz, 30:276, pl. 8, figs. 19-21. Hormosina ovulum (Grzybowski), Gradstein and Berggren, 1981, Mar. Micropaleontol., 6(3):246-248, pl. 2, figs. 1-2.

Rzehakina epigona (Rzehak). Silicina epigona, Rzehak, 1895, Ann. Naturhist. Mus. Wien, 10:214, pl. 6, fig. 1. Rzehakina epigona (Rzehak), Gradstein and Berggren, 1981, Mar. Micropaleontol., $6(3): 248$, pl. 5 , fig. 1 .

Thalmannammina walteri (Grzybowski). Haplophragmoides walteri, Grzybowski, 1898, Rozpr. Akad. Um. Krakowie, 33(2)13:280, pl. 10, fig. 24. Recurvoides ex. gr. walteri (Grzybowski), Gradstein and Berggren, 1981, Mar. Micropaleontol., 6(3):253, pl. 8, figs. $1-7$.

Trochamminoides velascoensis Cushman, 1926, Am. Assoc. Pet. Geol. Bull., 10(1):583, pl. 15, fig. 2a-b.

Spiroplectammina spectabilis (Grzybowski). Spiroplecta spectabilis, Grzybowski, 1898, Rozpr. Akad. Um. Krakowie, 33(2)13:293, pl. 12, fig. 12. Spiroplectammina spectabilis (Grzybowski), Gradstein and Berggren, 1981, Mar. Micropaleontol., 6(3):260, pl. 4, figs. $1-5$.

Textularia excolata Cushman, 1926, Am. Assoc. Pet. Geol. Bull., 10(1): 585 , pl. 15 , fig. $9 \mathrm{a}-\mathrm{b}$.

Textularia plummerae Lalicker, 1935, Contrib. Cushman Lab. Foram. Res., 11:50, pl. 6, fig. 10. Cushman, 1951, U.S. Geol. Surv. Prof. Pap., 232:7, pl. 2, figs. 2-3.

Gaudryina (Siphogaudryina) aissana, Ten Dam and Sigal, 1950, Contrib. Cushman Lab. Foram. Res., 1(1-2):31-32, pl. 2, fig. 2a-b.

Gaudryina inflata Israelsky, 1951, U.S. Geol. Surv. Prof. Pap., 240: 16, pl. 6, figs. 1-2. Aubert and Berggren, 1976, Bull. CRP-SNPA, $10(2): 410$, pl. 1 , fig. 11 .

Gaudryina pyramidata Cushman. Gaudryina laevigata Franke, var. pyramidata, Cushman, 1926. Am. Assoc. Pet. Geol. Bull., 10(1):587, pl. 16, fig. 8a-b.

Gaudryina retusa Cushman, 1926, Am. Assoc. Pet. Geol. Bull., 10(1): 588 , pl. 16, fig. 10a-b. Cushman, 1928, Contrib. Cushman Lab. Foram. Res., 4(4):92, pl. 13, figs. 3-4. 
Table 1. Occurrence and frequency of benthic foraminifers in Paleocene samples from Hole 605.

\begin{tabular}{|c|c|c|c|c|c|c|c|c|c|c|c|c|c|c|c|c|c|c|c|c|c|c|c|c|c|c|c|}
\hline $\begin{array}{c}\text { Core-Section } \\
\text { (interval in cm) }\end{array}$ & 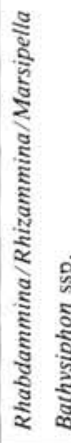 & & 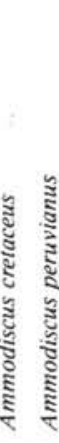 & 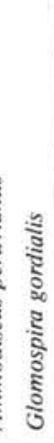 & 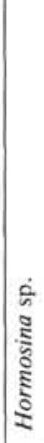 & 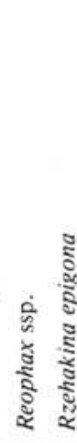 & 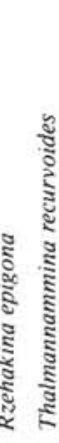 & 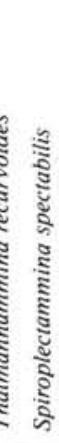 & 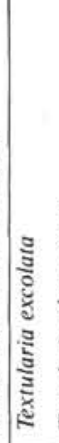 & 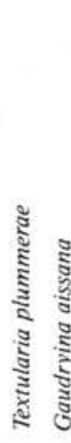 & 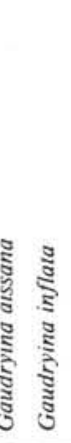 & 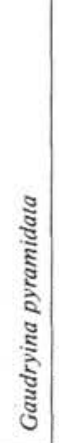 & 产 & 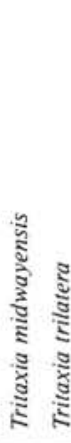 & 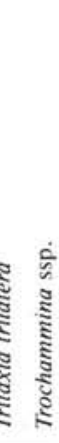 & 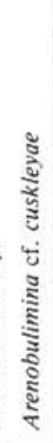 & 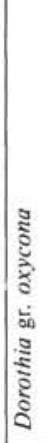 & 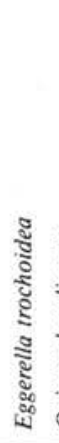 & 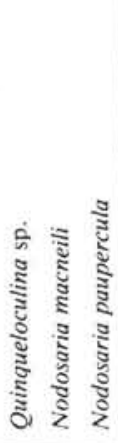 & 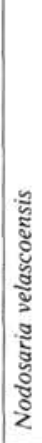 & 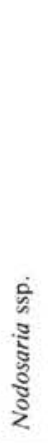 & 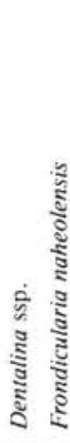 & 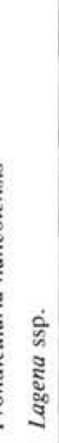 & 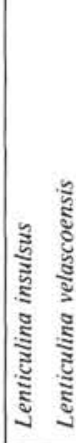 & 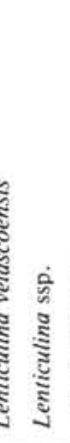 & 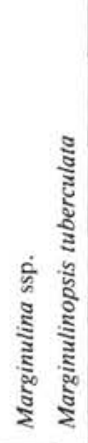 & 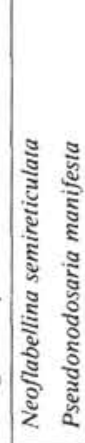 \\
\hline $\begin{array}{l}\text { Assemblage } 4 \\
\qquad \begin{array}{r}44-6,90-92 \\
45-2,90-92 \\
45-3,90-92 \\
45, \mathrm{CC} \\
46-2,90-92 \\
46-4,90-92 \\
46, \mathrm{CC} \\
47, \mathrm{CC}\end{array}\end{array}$ & $\begin{array}{ll}\mathrm{R} & \mathrm{R} \\
\mathrm{F} & \mathrm{A} \\
\mathrm{F} & \mathrm{F} \\
\mathrm{R} & \\
& \mathrm{R} \\
\mathrm{F} & \\
\mathrm{R} & \mathrm{C} \\
\mathrm{R} & \mathrm{F}\end{array}$ & $\begin{array}{ll}R & \\
A & \\
F & \\
R & F \\
C & V \\
F & \end{array}$ & $\begin{array}{ll} & R \\
& \\
F & F \\
V & V \\
V & V\end{array}$ & $\begin{array}{l}\mathrm{V} \\
\mathrm{V} \\
\mathrm{F}\end{array}$ & V & $\begin{array}{ll}\mathrm{V} & \\
\mathrm{R} & \\
\mathrm{V} & \\
& \mathrm{V} \\
& \mathrm{V} \\
\mathrm{V} & \mathrm{R} \\
& \mathrm{V}\end{array}$ & $\begin{array}{ll} & F \\
V & R \\
V & \\
R & R \\
V & R\end{array}$ & $\begin{array}{l}\mathrm{V} \\
\mathrm{R} \\
\mathrm{R} \\
\mathrm{R} \\
\mathrm{F} \\
\mathrm{R} \\
\mathrm{V}\end{array}$ & $\begin{array}{l} \\
\mathrm{V} \\
\mathrm{R}\end{array}$ & $\begin{array}{l}R \\
R \\
\text { V } \\
R \\
R\end{array}$ & $\begin{array}{l}\mathrm{F} \\
\mathrm{R} \\
\mathrm{V} \\
\mathrm{F} \\
\mathrm{V}\end{array}$ & $\begin{array}{l}\mathrm{R} \\
\mathrm{F} \\
\mathrm{F} \\
\mathrm{R} \\
\mathrm{F} \\
\mathrm{C} \\
\mathrm{F} \\
\mathrm{F}\end{array}$ & $\begin{array}{l}\mathrm{V} \\
\mathrm{R}\end{array}$ & $\begin{array}{l}\mathrm{F} \\
\mathrm{F}\end{array}$ & $\begin{array}{l}F \\
R \\
R \\
R \\
V \\
F\end{array}$ & $\begin{array}{l}\mathrm{F} \\
\mathrm{F} \\
\mathrm{V} \\
\mathrm{R} \\
\mathrm{R}\end{array}$ & $\begin{array}{l}\mathrm{V} \\
\mathrm{R} \\
\mathrm{R} \\
\mathrm{V} \\
\mathrm{V} \\
\mathrm{R}\end{array}$ & $\begin{array}{l}\mathrm{F} \\
\mathrm{R} \\
\mathrm{R} \\
\mathrm{F} \\
\mathrm{R} \\
\mathrm{R}\end{array}$ & $\begin{array}{ll}\mathrm{R} & \\
\mathrm{V} & \mathrm{V}\end{array}$ & V & $\begin{array}{l}\mathrm{V} \\
\mathrm{R} \\
\mathrm{F}\end{array}$ & $\begin{array}{l}R \\
R \\
R \\
F \\
R \\
R\end{array}$ & & $\begin{array}{l}\mathrm{R} \\
\mathrm{V}\end{array}$ & $\begin{array}{l}\mathrm{C} \\
\mathrm{C} \\
\mathrm{C} \\
\mathrm{F} \\
\mathrm{F} \\
\mathrm{R} \\
\mathrm{R}\end{array}$ & $\begin{array}{ll}\mathrm{F} & \\
\mathrm{F} & \\
\mathrm{R} & \\
\mathrm{F} & \\
& \mathrm{V} \\
\mathrm{R} & \\
\mathrm{F} & \\
\mathrm{V} & \end{array}$ & $v$ \\
\hline $\begin{array}{l}\text { Assemblage } 3 \\
\begin{array}{l}48, \mathrm{CC} \\
49-3,90-92 \\
50, \mathrm{CC} \\
51, \mathrm{CC} \\
52, \mathrm{CC}\end{array}\end{array}$ & $\begin{array}{ll} & \mathrm{R} \\
\mathrm{R} & \\
\mathrm{F} & \mathrm{C} \\
\mathrm{R} & \mathrm{V}\end{array}$ & $\begin{array}{ll}\mathrm{R} & \mathrm{R} \\
& \mathrm{R} \\
\mathrm{C} & \mathrm{V} \\
\mathrm{V} & \mathrm{V}\end{array}$ & $\begin{array}{ll}R & \\
R & R \\
V & \\
V & \end{array}$ & $\begin{array}{l}\mathrm{R} \\
\mathrm{V}\end{array}$ & & $\begin{array}{ll}\mathrm{F} \\
\mathrm{V}\end{array}$ & $\begin{array}{ll} & F \\
F & R \\
V & F\end{array}$ & $\begin{array}{l}\mathrm{V} \\
\mathrm{C} \\
\mathrm{F} \\
\mathrm{C} \\
\mathrm{C}\end{array}$ & $\begin{array}{l}\mathrm{R} \\
\mathrm{R} \\
\mathrm{R}\end{array}$ & $\begin{array}{l}\mathrm{R} \\
\mathrm{R} \\
\mathrm{F}\end{array}$ & $\begin{array}{l}\mathrm{R} \\
\mathrm{R} \\
\mathrm{F}\end{array}$ & $\begin{array}{l}\mathrm{F} \\
\mathrm{R} \\
\mathrm{R}\end{array}$ & $\begin{array}{l}\mathrm{V} \\
\mathrm{R}\end{array}$ & C $\begin{array}{l}\mathrm{C} \\
\mathrm{R} \\
\mathrm{R} \\
\mathrm{V}\end{array}$ & $\begin{array}{ll}C & V \\
& R \\
2 & \end{array}$ & v & $\begin{array}{l}\text { V } \\
\text { F } \\
\text { V }\end{array}$ & $\begin{array}{l}\mathrm{R} \\
\mathrm{V} \\
\mathrm{R} \\
\mathrm{R} \\
\mathrm{R}\end{array}$ & V & $\begin{array}{l}\mathrm{V} \\
\mathrm{V}\end{array}$ & & $\begin{array}{l}\mathrm{F} \\
\mathrm{R} \\
\mathrm{V}\end{array}$ & $\begin{array}{l}\mathrm{R} \\
\mathrm{V}\end{array}$ & R & $\begin{array}{l}\mathrm{F} \\
\mathrm{F} \\
\mathrm{F} \\
\mathrm{C} \\
\mathrm{F}\end{array}$ & $\begin{array}{l}\mathrm{F} \\
\mathrm{V}\end{array}$ & $v^{v}$ \\
\hline 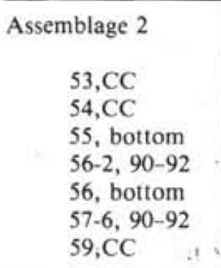 & $\begin{array}{lr}\mathrm{R} & \\
\mathrm{R} & \mathrm{R} \\
\mathrm{F} & \mathrm{F} \\
& \mathrm{V} \\
& \mathrm{F} \\
\mathrm{V} & \\
\mathrm{F} & \mathrm{F}\end{array}$ & $\begin{array}{ll}R & \\
F & \\
V & V \\
F & \\
F & V\end{array}$ & $\begin{array}{ll} & \mathrm{v} \\
\mathrm{v} & \\
\mathrm{v} & \mathrm{v} \\
\mathrm{v} & \end{array}$ & . & R & $\begin{array}{l}\mathrm{V} \\
\mathrm{R}\end{array}$ & $\begin{array}{l}\mathrm{R} \\
\mathrm{F} \\
\mathrm{R} \\
\mathrm{F} \\
\mathrm{C} \\
\mathrm{F} \\
\mathrm{V} \\
\mathrm{F}\end{array}$ & $\begin{array}{l}F \\
F \\
R \\
V \\
V\end{array}$ & R & $\begin{array}{l}\text { V } \\
\text { V }\end{array}$ & $\begin{array}{ll}\mathrm{V} & \\
\mathrm{V} & \\
\mathrm{v}\end{array}$ & $\begin{array}{l}\mathrm{V} \\
\mathrm{F} \\
\mathrm{F} \\
\mathrm{V} \\
\mathrm{R}\end{array}$ & $\begin{array}{ll}\mathrm{V} \\
\mathrm{V} \\
\mathrm{R} \\
\mathrm{V} \\
\mathrm{V} \\
\mathrm{V} \\
\end{array}$ & $\begin{array}{ll} & \mathrm{F} \\
& \mathrm{R} \\
\mathrm{F} & \\
\mathrm{R} & \\
\mathrm{C} & \\
\mathrm{C} & \\
\mathrm{F} & \end{array}$ & $\begin{array}{ll}\mathrm{F} & \mathrm{V} \\
\mathrm{R} & \mathrm{F}\end{array}$ & $\mathrm{v}$ & $\begin{array}{l}\mathrm{v} \\
\mathrm{v} \\
\mathrm{v} \\
\mathrm{v}\end{array}$ & $\begin{array}{l}\mathrm{R} \\
\mathrm{V} \\
\mathrm{R} \\
\mathrm{V} \\
\mathrm{V} \\
\mathrm{V} \\
\mathrm{R} \\
\mathrm{R}\end{array}$ & $\mathrm{R}$ & $\begin{array}{l}\mathrm{V} \\
\mathrm{R}\end{array}$ & $\begin{array}{l}\text { C } \\
F \\
R \\
\text { V } \\
R \\
\text { V }\end{array}$ & $\begin{array}{l}R \\
F \\
R \\
R \\
R \\
V\end{array}$ & & $\begin{array}{lll}\mathrm{F} & & \\
\mathrm{R} & & \\
& & \\
& \mathrm{F} \\
\mathrm{C} & & \end{array}$ & $\begin{array}{l}\mathrm{C} \\
\mathrm{R} \\
\mathrm{C} \\
\mathrm{F} \\
\mathrm{F} \\
\mathrm{F} \\
\mathrm{F} \\
\mathrm{R}\end{array}$ & $\begin{array}{l}\mathrm{F} \\
\mathrm{R} \\
\mathrm{F} \\
\mathrm{V} \\
\mathrm{R} \\
\mathrm{V} \\
\mathrm{V}\end{array}$ & $\mathrm{v}$ \\
\hline 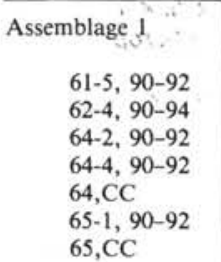 & $\begin{array}{ll}F & C \\
F & F \\
F & C \\
R & F\end{array}$ & $\begin{array}{ll} & R \\
C & V \\
F & \\
C & \\
F & \end{array}$ & $\begin{array}{l}R \\
V\end{array}$ & F & F & $\begin{array}{l}\mathrm{R} \\
\mathrm{C} \\
\mathrm{F} \\
\mathrm{R}\end{array}$ & $\begin{array}{l}\mathrm{R} \\
\mathrm{F} \\
\mathrm{A} \\
\mathrm{R}\end{array}$ & $\begin{array}{l}R \\
R \\
V \\
F\end{array}$ & & & & $\begin{array}{l}\mathrm{R} \\
\mathrm{R} \\
\mathrm{F}\end{array}$ & & $\begin{array}{r}A \\
v \quad v\end{array}$ & $\begin{array}{l}\mathrm{V} \\
\mathrm{F} \\
\mathrm{C}\end{array}$ & $\begin{array}{l}R \\
R \\
R\end{array}$ & $\begin{array}{l}\mathrm{R} \\
\mathrm{F} \\
\mathrm{C}\end{array}$ & R & & $\mathrm{v}$ & $\begin{array}{l}\mathrm{C} \\
\mathrm{F} \\
\mathrm{V} \\
\mathrm{C}\end{array}$ & $R^{V}$ & $\begin{array}{l}\mathrm{F} \\
\mathrm{R}\end{array}$ & & $\begin{array}{l}C \\
F \\
V \\
R \\
R \\
R\end{array}$ & $\begin{array}{l}\mathrm{v} \\
\mathrm{v}\end{array}$ & R \\
\hline
\end{tabular}

Note: $\mathrm{V}=$ very rare, $\mathrm{R}=$ rare, $\mathrm{F}=$ frequent, $\mathrm{C}=$ common, $\mathrm{A}=$ abundant.

Tritaxia midwayensis (Cushman). Clavulinoides midwayensis, Cushman, 1936, Cushman Lab. Foram. Res. Spec. Publ., 6:21, pl. 3, figs. 9, 15. Tritaxia midwayensis (Cushman), Berggren and Aubert, 1975, Palaeogeogr. Palaeoclimatol., Palaeoecol., 18:142, pl. 1, fig. 1a-e.

Tritaxia trilatera (Cushman). Clavulina trilatera, Cushman, 1926, Am. Assoc. Pet. Geol. Bull., 10:588, pl. 17, fig. 2. Tritaxia trilatera (Cushman), Proto Decima and Bolli, 1978, Init. Repts. DSDP, 40: 796, pl. 1, fig. 8 .

Trochammina deformis Grzybowski, 1898, Rozpr. Akad. Um. Krakowie, 33(2)13:288, pl. 11, figs. 20-22. Gradstein and Berggren, 1981, Mar. Micropaleontol., 6:256, pl. 8, fig. 8-10.

Arenobulimina cuskleyae Jennings, 1936, Bull. Am. Paleontol., 23(28):

13, pl. 1, fig. 8. Pozaryska, 1968, Paleontol. Polonica, 20:36, fig. 5.

Dorothia oxycona (Reuss). Gaudryina oxycona, Reuss, 1860, K. Akad. Wiss. Wien, 40:229, pl. 12, fig. 3. Dorothia oxycona (Reuss), Aubert and Berggren, 1976, Bull. CRP-SNPA, 10(2):410, pl. 1, fig. 14.
Eggerella trochoides (Reuss). Verneuilina trochoides Reuss, 1860, $K$. Akad. Wiss. Wien, 40. Cushman and Renz, 1946, Cushman Lab. Foram. Res. Spec. Publ., 18:22, pl. 2, fig. 20.

Nodosaria macneili Cushman, 1944, Contr. Cushman Lab. Foram. Res., 20(2):37, pl. 6, fig. 9. Aubert and Berggren, 1976, Bull. CRP-SNPA, 10(2):412, pl. 2, fig. 6.

Nodosaria paupercula Reuss, 1845, Die Versteinerungen der Böhmische Kreideformation (Stuttgart), 1:26, pl. 12, fig. 12. Aubert and Berggren, 1976, Bull. CRP-SNPA, 10(2):413, pl. 2, fig. 7.

Frondicularia naheolensis Cushman and Todd, 1942, Cushman Lab. Foram Res., 18:33, pl. 6, figs. 5-6.

Lenticulina insulsus Cushman, 1947, Contr. Cushman Lab. Foram. Res., 23:83, pl. 18, figs. 2-3.

Lenticulina velascoensis White, 1928, J. Paleontol., 2(3):199, pl. 28, fig. 8.

Nodosaria velascoensis Cushman. Nodosaria fontannesi (Berthelin), var. velascoensis, Cushman, 1926, Am. Assoc. Pet. Geol. Bull., 10:594, pl. 18, fig. 12 . 
Table 1 (continued).

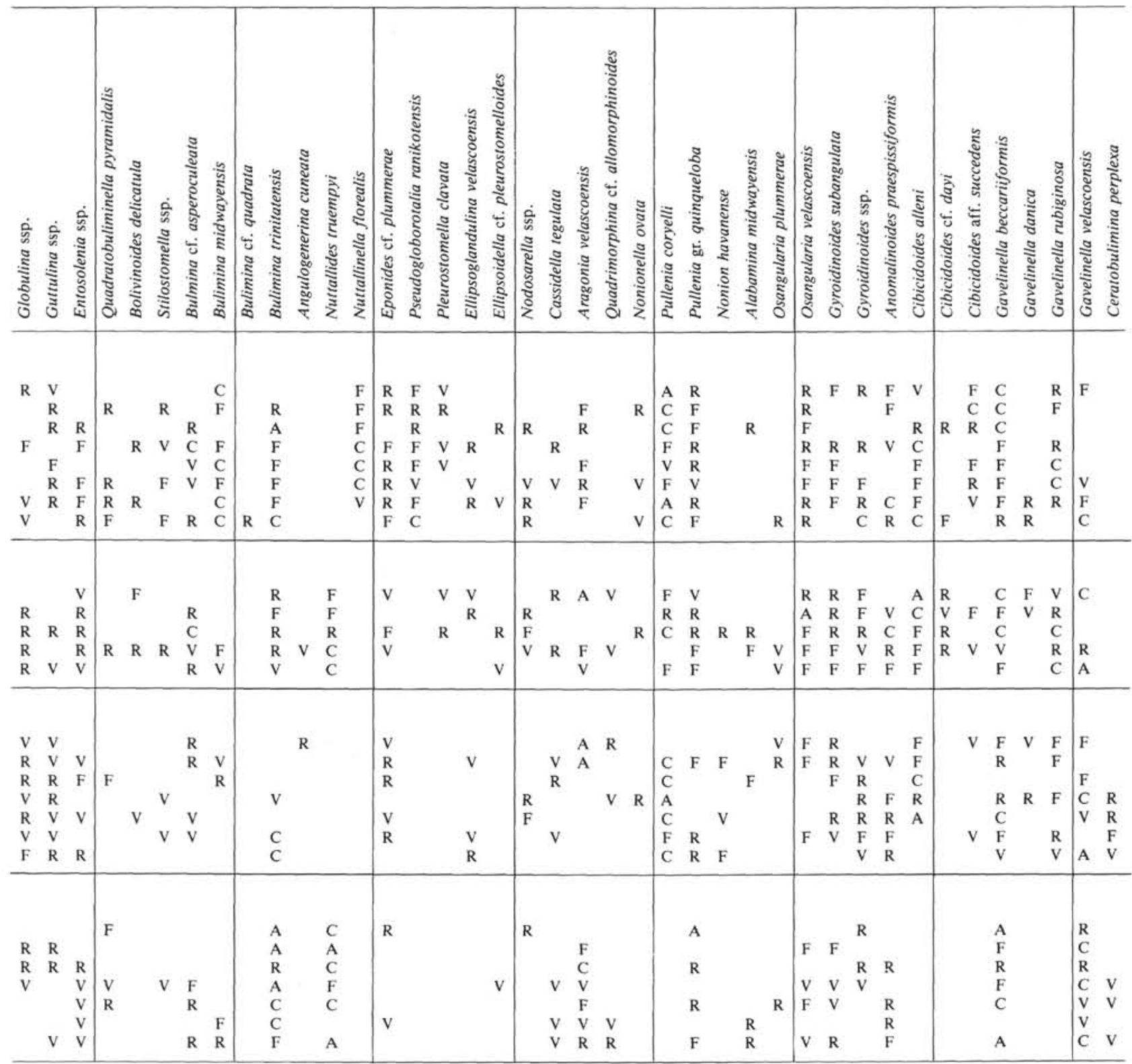

Marginulinopsis tuberculata (Plummer). Cristellaria subaculeata Cushman, var. tuberculata, Plummer, 1926, Texas Univ. Bull., 2644: 101, pl. 7, fig. 2; pl. 14, fig. 1a-c. Marginulinopsis tuberculata (Plummer), Aubert and Berggren, 1976, Bull. CRP-SNPA, 10(2): 416 , pl. 3, fig. 6 .

Pseudonodosaria manifesta (Reuss). Glandulina manifesta, Reuss, 1851, Haidinger's Naturwiss. Abh., 4(1):22, pl. 1, fig. 4. Pseudoglandulina manifesta (Reuss), Cushman, 1951, U.S. Geol. Surv. Prof. Pap., 232:25, pl. 7, figs. 16-17.

Quadratobuliminella pyramidalis De Klasz, 1953, Neues Jahrb. Paläont., 10:435.

Bolivinoides delicatula Cushman. Bolivinoides decorata (Jones), var. delicatula, Cushman, 1927, Contr. Cushman Lab. Foram. Res., 2(4):90, pl. 12, fig. 8.

Bulimina asperoculeata Brotzen, 1948, Sver. Geol. Unders., 493:60, pl. 6, fig. 4; pl. 10, figs. 6-7. Aubert and Berggren, 1976, Bull. CRP-SNPA, 10(2):421, pl. 5, fig. 4a-c.

Bulimina midwayensis Cushman and Parker. Bulimina arkadelphiana Cushman and Parker, var. midwayensis, Cushman and Parker,
1936, Contr. Cushman Lab. Foram. Res., 12:42, pl. 7, fig. 9. Bulimina midwayensis Cushman and Parker, Aubert and Berggren, 1976, Bull. CRP-SNPA, 10(2):422,. pl. 5, fig. 7.

Bulimina (Ellipsobulimina) quadrata Plummer, 1926, Texas Univ. Bull., 2644:72, pl. 4, figs. 4-5.

Bulimina trinitatensis Cushman and Jarvis, 1928, Contr. Cushman Lab. Foram. Res., 4(4):102, pl. 14, fig. 12a-b. Aubert and Berggren, 1976, Bull. CRP-SNPA, 10(2):423, pl. 5, fig. 12a-b.

Angulogenerina cuneata Brotzen, 1948, Sver. Geol. Unders., 493:64, pl. 6 , fig. 10 .

Nuttallides truempyi (Nuttall). Eponides trümpyi, Nuttall, 1930, J. Paleontol., 4(3):287, pl. 24, figs. 9, 13, 14. Bermudez, 1949, Cushman Lab. Foram. Res. Spec. Publ., 25:249, pl. 17, figs. 16-18. Nuttallides truempyi (Nuttall), Proto Decima and Bolli, 1978, Init. Repts. DSDP, 40:795, pl. 3, fig. 1-2.

Nuttallinella florealis (White). Gyroidina florealis, White, 1928, J. Paleontol., 2(4):293, pl. 40, fig. 3. Charltonia florealis (White), Proto Decima and Bolli, 1978, Init Repts. DSDP, 40:791, pl. 4, fig. $17-18$. 
Table 2. Main species of benthic foraminifers present in Site 237 (Indian Ocean; Vincent et al., 1974), Site 329 (South Atlantic; Tjalsma, 1977), and Site 605 (North Atlantic; this chapter).

\begin{tabular}{|c|c|c|c|}
\hline Foraminifers & Site 237 & Site 329 & Site 605 \\
\hline Alabamina midwayensis & & & $\mathrm{x}$ \\
\hline Anomalinoides midwayensis & $\mathrm{x}$ & & \\
\hline A. praespissiforamis & & & $\mathrm{x}$ \\
\hline A. welleri & $\mathrm{x}$ & & \\
\hline Aragonia aragonensis & $x$ & $\mathrm{x}$ & \\
\hline A. velascoensis & & & $\mathrm{x}$ \\
\hline Bolivinoides delicatula & & $\mathrm{x}$ & $\mathrm{x}$ \\
\hline Bulimina asperoculeata & & & $\mathrm{x}$ \\
\hline $\begin{array}{l}\text { B. jarvisi } \\
\text { B. midwayensis }\end{array}$ & & $\mathrm{x}$ & \\
\hline B. midwayensis & & & $\mathrm{x}$ \\
\hline B. trinitatensis & & $\mathrm{x}$ & $x$ \\
\hline Cassidella tegulata & & & $x$ \\
\hline $\begin{array}{l}\text { Cibicidoides alleni } \\
\text { C. dayi }\end{array}$ & $\mathrm{x}$ & & $\begin{array}{l}x \\
x\end{array}$ \\
\hline $\begin{array}{l}\text { C. dayi } \\
\text { C. cf. succedens }\end{array}$ & & & $\begin{array}{l}x \\
x\end{array}$ \\
\hline C. cf. succedens & & & $x$ \\
\hline Dentalina eocenica & $\mathrm{x}$ & & $x$ \\
\hline Dorothia oxycona & $\mathrm{x}$ & & $\mathrm{x}$ \\
\hline Eggerella trochoidea & & & $\mathrm{x}$ \\
\hline Eponides plummerae & & & $\mathbf{x}$ \\
\hline Frondicularia jarvisi & & $\mathrm{x}$ & \\
\hline F. naheolensis & $\mathrm{x}$ & & $x$ \\
\hline Gaudryina taevigata & $\mathrm{x}$ & $\mathrm{x}$ & \\
\hline G. pyramidata & & $\mathbf{x}$ & $\mathrm{x}$ \\
\hline G. retusa & & & $x$ \\
\hline Gavelinella aragonensis & & $\mathrm{x}$ & \\
\hline G. beccariiformis & $\mathrm{x}$ & $\mathrm{x}$ & $\mathrm{x}$ \\
\hline G. danica & $\mathrm{x}$ & $\mathrm{x}$ & $\mathrm{x}$ \\
\hline G. rubiginosa & & & $\mathrm{x}$ \\
\hline G. velascoensis & & & $x$ \\
\hline Gyroidinoides subangulata & & & $x$ \\
\hline G. globosa & $\mathrm{x}$ & $\mathrm{x}$ & $\mathrm{x}$ \\
\hline Lenticulina degolyeri & $\mathrm{x}$ & & \\
\hline L. insulsus & $\mathrm{x}$ & & $\mathrm{x}$ \\
\hline L. midwayensis & $x$ & & \\
\hline L. velascoensis & $\mathrm{x}$ & & $\mathrm{x}$ \\
\hline Neoflabellina jarvisi & & $\mathrm{x}$ & \\
\hline N. semireticulata & & & $\mathrm{x}$ \\
\hline Nodosaria latejugata & $\mathrm{x}$ & & \\
\hline N. velascoensis & $\mathrm{x}$ & $\mathrm{x}$ & $\mathbf{x}$ \\
\hline Nonionella ovata & & $\mathrm{x}$ & $\mathrm{x}$ \\
\hline Nuttallides truempyi & $\mathrm{x}$ & $\mathrm{x}$ & $\mathrm{x}$ \\
\hline Nuttallinella florealis & & & $\mathrm{x}$ \\
\hline Oridorsalis umbonatus & $\mathbf{x}$ & $\mathrm{x}$ & \\
\hline Osangularia culter & $\mathrm{x}$ & & \\
\hline O. plummerae & & & $\mathrm{x}$ \\
\hline$O$. velascoensis & & & $\mathrm{x}$ \\
\hline Pleurostomella paleocenica & $\mathrm{x}$ & & \\
\hline Pseudonodosaria manifesta & $\mathrm{x}$ & & $\mathrm{x}$ \\
\hline Pseudogloborotalia ranikotensis & & & $\begin{array}{l}x \\
x\end{array}$ \\
\hline Pullenia coryelli & $\mathrm{x}$ & $x$ & $\mathrm{x}$ \\
\hline P. jarvisi & & $\mathbf{x}$ & $\mathrm{x}$ \\
\hline P. quinqueloba & $x$ & $x$ & $x$ \\
\hline Quadrimorphina allomorphinoides & $x$ & $x$ & $x$ \\
\hline Spiroplectammina spectabilis & $\mathrm{x}$ & $\mathrm{x}$ & $x$ \\
\hline Stilostomella paleocenica & $x$ & & $x$ \\
\hline Textularia excolata & & & $\mathrm{x}$ \\
\hline T. plummerae & $\mathrm{x}$ & & $\mathrm{x}$ \\
\hline Thalmannammina walteri & & & $\mathrm{x}$ \\
\hline Tritaxia midwayensis & & $\mathrm{x}$ & $\mathrm{x}$ \\
\hline T. trilatera & & & $\mathrm{x}$ \\
\hline $\begin{array}{l}\text { Tappanina selmensis } \\
\text { Vaginulina longiforma }\end{array}$ & $\mathrm{x}$ & $\mathbf{x}$ & \\
\hline
\end{tabular}

Eponides plummerae Cushman, 1948, Contr. Cushman Lab. Foram. Res., 24(2):44, pl. 8, fig. 9.

Pseudogloborotalia ranikotensis Haque, 1956, Geol. Surv. Pakistan, Palaeont. Pakistanica, 1:184.

Nonionella ovata Brotzen, 1948, Sver. Geol. Undes., 493:69, pl. 10, figs. 13-14.

Pullenia coryelli White, 1929, J. Paleontol., 3(1):56, pl. 5, fig. 22. Proto Decima and Bolli, 1978, Init. Repts. DSDP, 40:795, pl. 4, fig. 3-4.

Pullenia puentapiedraensis Galloway and Morrey, 1931, J. Paleontol., $5: 341$, pl. 38, fig. 11 .

Pullenia gr. quinqueloba (Reuss). Nonionina quinqueloba Reuss, 1851, Z. D. Geol. Ges., Vol. 3. Plummer, 1926, Texas Univ. Bull., 2644: 136, pl. 8, fig. 12a-b.

Alabamina midwayensis Brotzen, 1948, Sver. Geol. Unders., 493:99, pl. 16, figs. 1-2. Berggren and Aubert, 1975, Palaeogeogr. Palaeoclimatol., Palaeoecol., 18:147, pl. 2, fig. 14a-c.

Osangularia plummerae Brotzen, 1948, Sver. Geol. Unders., 493:30, text-fig. 8. Berggren and Aubert, 1975, Palaeogeogr. Palaeoclimatol. Palaeoecol., 18:147, pl. 3, fig. 6a-g.

Osangularia velascoensis (Cushman). Truncatulina velascoensis, Cushman, 1925, Contr. Cushman Lab. Foram. Res., (1):20, pl. 3, fig. 2a-c.

Gyroidinoides subangulata (Plummer), Rotalia soldanii (d'Orbigny) var. subangulata, Plummer, 1926, Texas Univ. Bull., 2644:154, pl. 12, fig. 1a-c. Gyroidinoides subangulata (Plummer), Berggren and Aubert, 1975, Palaeogeogr., Palaeoclimatol., Palaeoecol., 18: 148 , pl. 3, fig. 2a-c.

Anomalinoides praespissiformis (Cushman and Bermudez). Anomalina praespissiformis, Cushman and Bermudez, 1948, Contr. Cushman Lab. Foram. Res., 24:86, pl. 15, figs. 1-3.

Cibicidoides alleni (Plummer). Truncatulina alleni, Plummer, 1926, Texas Univ. Bull., 2644:144, pl. 10, fig. 4a-c. Cibicidoides alleni (Plummer), Berggren and Aubert, 1975, Palaeogeogr., Palaeoclimatol., Palaeoecol., 18:151, pl. 5, fig. 1a-d; pl. 7, fig. 1-3.

Cibicidoides dayi (White). Planulina dayi, White, 1928, J. Paleont., 2(4):300, pl. 41, fig. 3. Cibicidoides dayi (White), Aubert and Berggren, 1976, Bull. CRP-SNPA, 10(2):431, pl. 10, fig. 3a-c.

Cibicidoides succedens (Brotzen). Cibicides succedens, Brotzen, 1948, Sver. Geol. Unders., 493:80, pl. 12, fig. 1. Cibicidoides succedens (Brotzen), Berggren and Aubert, 1975, Palaeogeogr., Palaeoclimatol., Palaeoecol., 18:154, pl. 14, fig. 5.

Gavelinella beccariiformis (White). Rotalia beccariiformis, White, 1928, J. Paleontol., 2(4):287, pl. 39, figs. 2-4. Gavelinella beccariiformis (White), Aubert and Berggren, 1976, Bull. CRP-SNPA, 10(2):433, pl. 11, fig. 4a-c.

Gavelinella danica (Brotzen). Cibicides danica, Brotzen, 1948, Sver. Geol. Unders., 435:31, fig. 7. Gavelinella danica (Brotzen), Berggren and Aubert, 1975, Palaeogeogr., Palaeoclimatol., Palaeoecol., $18: 155$, pl. 6, fig. 3a-b.

Gavelinella rubiginosa (Cushman). Anomalina rubiginosa, Cushman, 1926, Am. Assoc. Pet. Geol. Bull., 10(6):607, pl. 21, fig. 6a-c. Gavelinella rubiginosa (Cushman), Aubert and Berggren, 1976, Bull. CRP-SNPA, 10(2):433, pl. 12, fig. 3a-c.

Gavelinella velascoensis (Cushman). Anomalina velascoensis, Cushman, 1925, Contr. Cushman Lab. Foram. Res., 1(1):21, pl. 3, fig. 3a-c. Gavelinella velascoensis (Cushman), Aubert and Berggren, 1976, Bull. CRP-SNPA, 10(2): pl. 12, fig. 4.

Ceratobulimina perplexa (Plummer). Rotalia perplexa, Plummer, 1926, Texas Univ. Bull., 2644:156, pl. 12, fig. 2a-c. Ceratobulimina perplexa (Plummer), Berggren and Aubert, 1975, Palaeogeogr., Palaeoclimatol., Palaeoecol., 18:157, pl. 10, fig. 11.

\section{ACKNOWLEDGMENTS}

I wish to thank the Deep Sea Drilling Project and especially the paleontologists of Leg 93, Dr. J. E. van Hinte (Amsterdam University) and Dr. M. Moullade (Nice University), for making this material available for study. I would also like to thank Dr. W. A. Berggren (Woods Hole Oceanographic Institution) who kindly read the manuscript and suggested improvements, and Dr. D. A. Dunn (University of Southern Mississippi), Dr. K. G. Miller (Lamont-Doherty Geological Observatory), Dr. B. Corliss (Duke University), and Ms. E. Whalen (DSDP editor), who reviewed this paper. 


\section{REFERENCES}

Aubert, J., and Berggren, W. A., 1976. Paleocene benthic foraminiferal biostratigraphy and paleoecology of Tunisia. Cen. Rech. PauSNPA Bull., 10(2):379-469.

Berggren, W. A., 1978. Recent advances in Cenozoic planktonic foraminiferal biostratigraphy, biochronology, and biogeography: Atlantic Ocean. Micropaleontology, 24 (4):337-370.

Berggren, W. A., and Aubert, J., 1975. Paleocene benthonic foraminiferal biostratigraphy, paleobiogeography and paleoecology of Atlantic-Tethyan regions: Midway-type fauna. Palaeogeogr., Palaeoclimatol., Palaeoecol., 18:73-193.

1983. Paleogene benthic foraminiferal biostratigraphy and paleobathymetry of the central Ranges of California. U.S. Geol. Surv. Prof. Pap., 1213:4-21.

Berggren, W. A., and Schnitker, D., 1983. Cenozoic marine environments in the North Atlantic and Norwegian-Greenland Sea. In Bott, M. H. P., Saxov, Talwani, M., and Thiede, J. (Eds.), Structure and Development of the Greenland-Scotland Ridge: New York (Plenum), pp. 495-548.

Boersma, A., and Premoli Silva, I., 1983. Paleocene planktonic foraminiferal biogeography and the paleoceanography of the Atlantic Ocean. Micropaleontology, 29(4):355-381.

Bolli, H. M., 1966. Zonation of Cretaceous to Pliocene marine sediments based on planktonic foraminifera. Assoc. Venez. Geol. Min. Pet., 9:3-32.

Cushman, J. A., 1926. The foraminifera of the Velasco shale of the Tampico Embayment. Am. Assoc. Pet. Geol. Bull., 10(1):581-612.

Cushman, J. A., and Renz, H. H., 1946. The Foraminiferal Fauna of the Lizard Springs Formation of Trinidad, British West Indies. Cushman Lab. Foram. Res. Spec. Publ., 18.

Douglas, R., and Woodruff, F., 1981. Deep-sea benthic foraminifera. In Emiliani, C. (Ed.), The Oceanic Lithosphere (Vol. 7): New York (Wiley), 1233-1327.

Haq, B. U., Premoli Silva, I., and Lohmann, G. P., 1977. Calcareous plankton paleobiogeographic evidence from major climatic fluctuations in the Early Cenozoic Atlantic Ocean. J. Geophys. Res., 82(27):3861-3876.

Hardenbol, J., and Berggren, W. A., 1978. A new Paleogene numerical time scale. Am. Assoc. Pet. Geol. Stud. Geol., 6:213-234.

McGowran, B., 1966. Australian Paleocene Lamarckina and Ceratobulimina, with a discussion of Cerobertina, Pseudobulimina, and the family Robertinidae. Contr. Cushman Foram. Res., 17(3):17103.

Proto Decima, F., and Bolli, H. M., 1978. Southeast Atlantic DSDP Leg 40 Paleogene benthic foraminifers. In Bolli, H. M., Ryan, W. B. F., et al., Init. Repts. DSDP, 40: Washington (U.S. Govt. Printing Office), 783-809.

Schnitker, D., 1979. Cenozoic deep water benthic foraminifers, Bay of Biscay, In Montadert, L, Roberts, D. G., et al., Init. Repts. DSDP, 48: Washington (U.S. Govt. Printing Office), 377-414.

Stainforth, R. M., Lamb, J. L., Luterbacher, H., Beard, J. H., and Jeffords, R. M., 1975. Cenozoic Planktonic Foraminiferal Zonation and Characteristics of Index Forms. Univ. Kansas Paleontol. Contrib., 62.

Tjalsma, R. C., 1977. Cenozoic foraminifera from the South Atlantic, DSDP Leg 36 In Barker, P. F., Dalziel, I. W. D., et al., Init. Repts. DSDP, 36: Washington (U.S. Govt. Printing Office), 493-517.

Tjalsma, R. C., and Lohmann, G. P., 1983. Paleocene-Eocene Bathyal and Abyssal Benthic Foraminifera from the Atlantic Ocean. Micropaleontology, Spec. Publ. 4.

Vail, P. R., Mitchum, R. M., and Thompson, S., 1977. Seismic stratigraphy and global changes of sea level, Part 4: Global cycles of relative changes of sea level. Am. Assoc. Pet. Geol. Mem., 26: 83-97.

Vincent, E., Gibson, J. M., and Brun, L., 1974. Paleocene and early Eocene microfacies, benthonic foraminifera, and paleobathymetry of deep sea drilling project, Sites 236 and 237, western Indian Ocean. In Fisher, R. L., Bunce, E. T., et al., Init. Repts. DSDP, 24: Washington (U.S. Govt. Printing Office), 859-885.

Webb, P. N., 1972. Upper Cretaceous-Paleocene foraminifera from Site 208 (Lord Howe Rise, Tasman Sea), DSDP, Leg 21. In Burns, R. E., Andrews, J. E., et al., Init. Repts. DSDP, 21: Washington (U.S. Govt. Printing Office), 541-574.

White, M. P., 1928-1929. Some index foraminifera of the Tampico Embayment area of Mexico. Part 1: J. Paleontol., 2(3):177-215. Part II: J. Paleontol., 2(4):280-317. Part III: J. Paleontol., 3(1): 30-58.

Date of Initial Receipt: 24 January 1985

Date of Acceptance: 24 October 1985 